\title{
Analisis pengaruh nilai tukar, pertumbuhan ekonomi dan tenaga kerja terhadap ekspor Indonesia dan Malaysia ke China.
}

\author{
Candra Mustika*; Erni Achmad
}

Prodi Ekonomi Pembangunan, Fak. Ekonomi dan Bisnis, Universitas Jambi

*E-mail. korespondesi: candra.mustika@yahoo.com

\begin{abstract}
The purpose of this study was to determine and analyze the development of exchange rates, labor, and economic growth, and exports of Indonesia and Malaysia to China from 1993 to 2015 and to analyze the effect of exchange rates, labor, and economic growth on Indonesian and Malaysian exports to China from 1993 to 2015 Based on the results of research The development of Indonesian exports to China fluctuated or fluctuated during the period 1993 to 2015 with an average of 13.95\%, while the rupiah exchange rate against the United States dollar and economic growth also fluctuated the average growth the rupiah exchange rate against the United States dollar was $14.52 \%$, and the average economic growth of $4.69 \%$ labor also fluctuated with an average growth of $1.72 \%$. Based on the results of the panel data regression shows the exchange rate variable has a significant negative effect on exports to China, the labor variable has a positive and significant effect on exports to China, while the economic growth variable has no significant effect on exports to China.
\end{abstract}

Keywords: Export to China, Exchange rate, Economic growth, Labor

\begin{abstract}
Abstrak
Tujuan penelitian ini adalah untuk mengetahui dan menganalisis perkembangan nilai tukar, tenaga kerja dan pertumbuhan ekonomi serta ekspor Indonesia dan Malaysia ke China dari tahun 1993 sampai tahun 2015 dan Untuk menganalisis pengaruh Nilai Tukar,Tenaga kerja dan pertumbuhan ekonomi terhadap ekspor Indonesia dan Malaysia ke china dari tahun 1993 sampai tahun 2015 Berdasarkan hasil penelitian Perkembangan ekspor Indonesia ke china berfluktuasi atau naik turun selama periode tahun 1993 sampai 2015 dengan rata-rata 13,95\%,sementara nilai tukar rupiah terhadap dolar amerika serikat serta pertumbhan ekonomi juga berfluktuasi rata-rata pertumbuhan nilai tukar rupiah terhadap dolar amerika serikat sebesar $14,52 \%$, dan rata-rata pertumbuhan ekonomi sebesar 4,69\% tenaga kerja juga berfluktuasi dengan rata-rata pertumbuhan $1,72 \%$. Berdasarkan hasil regresi data panel menunjukkan variabel kurs berpengaruh negatif signifikan terhadap ekspor ke china, variabel tenaga kerja berpengaruh positif dan signifikan terhadap ekspor ke china, sementara variabel pertumbuhan ekonomi tidak berpengaruh signifikan terhadap ekspor ke china.
\end{abstract}

Kata kunci: Ekspor ke China, Kurs, Pertumbuhan ekonomi, Tenaga kerja

\section{PENDAHULUAN}

Dalam perekonomian modern saat ini hampir setiap Negara di dunia ini yang menganut sistem perekonomian terbuka dengan melakukan perdagangan dan kerja sama 
ekonomi dengan Negara lain. Perbedaan sumber daya alam dan sumber daya manusia merupakan salah satu faktor utama yang menyebabkan perbedaan keunggulan antar satu Negara dengan Negara lainnya sehingga masing-masing Negara memiliki spesialisasi keunggulan tersendiri tergantung keadaan faktor produksimnya seperti sumber daya alam dan sumber daya manusia karena perbedaan faktor produksi hampir tidak ada satu pun Negara yang mampu memenuhi kebutuhannya sendiri sehingga butuh kerjasama menjalin perdagangan dengan Negara lain.

Dalam era globalisasi yang telah berkembang saat ini dengan kemajuan teknologi menyebabkan kemudahan transportasi dan komunikasi sehingga setiap Negara semakin mudah untuk menjalin kerjasama dengan Negara lainnya termasuk kerjasama perdagangan internasional yang meliputi kegiatan ekspor dan impor. Indonesia dan Malaysia merupakan dua Negara yang saling bertetangga karena berada di kawasan yang sama yakni di benua Asia tepatnya Asia tenggara. Dan saat ini Negara yang berada di kawasan Asean menjalin hubungan kerjasama perdagangan bebas dengan china melalui ACFTA (Asian China Free Trade Agreement) menurut catatan Bank Pembangunan Asia ekspor Indonesia ke China pada tahun 2014 senilai 17,606 Juta US Dollar sementara Nilai ekspor Malaysia ke China pada tahun 2014 senilai 28.204 Juta US Dollar, diharapkan dengan adanya perdagangan dengan china salah satu Negara yang memiliki jumlah penduduk paling besar sehingga tingkat konsumsi masyarakatnya pun akan tinggi dan ini adalah peluang yang cukup besar untuk meningkatkan ekspor Negara Indonesia dan Malaysia ke china. Secara teoritis banyak sekali faktor yang mempengaruhi ekspor ke dua Negara tersebut ke china dan hal itu dapt dilihat dari sisi permintaan yang ditinjau dari Negara tujuan ekspor yakni china dan sisi penawaran yang ditinjau dari Negara eksportir yakni Indonesia dan Malaysia.

Teori keunggulan mutlak dikemukakan oleh Adam Smith (1776) dalam bukunya The Wealth of Nation. Adam Smith menganjurkan perdagangan bebas sebagai kebijakan yang mampu mendorong kemakmuran suatu negara. Dalam perdagangan bebas, setiap negara dapat menspesialisasikan diri dalam produksi komoditas yang memiliki keunggulan mutlak/absolut dan mengimpor komoditi yang memperoleh kerugian mutlak.

Teori keuntungan komparatif ini dikembangkan oleh David Ricardo, yang menyatakan bahwa setiap negara akan memperoleh keuntungan jika ia menspesialisasikan pada produksi dan ekspor yang dapat diproduksinya pada biaya yang relatif lebih murah, dan mengimpor apa yang dapat diprosuksinya pada biaya yang relatif lebih mahal.

Kuzmets dalam Jhingan (1993) mendefinisikan pertumbuhan ekonomi sebagai kenaikan jangka panjang dalam kemampuan suatu negara untuk menyediakan semakin banyak jenis barang-barang ekonomi kepada penduduknya, kemampuan ini tumbuh sesuai dengan kemajuan teknologi dan penyesuaian kelembagaan dan ideologis yang diperlukannya. Definisi ini memiliki 3 (tiga) komponen: pertama, pertumbuhan ekonomi suatu bangsa terlihat dari meningkatnya secara terus menerus persediaan barang; kedua, teknologi maju merupakan faktor dalam pertumbuhan ekonomi yang menentukan derajat pertumbuhan kemampuan dalam penyediaan aneka macam barang kepada penduduk; ketiga, penggunaan teknologi secara luas dan efisien memerlukan adanya penyesuaian dibidang kelembagaan dan ideologi sehingga inovasi yang dihasilkan oleh ilmu pengetahuan umat manusia dapat dimanfaatkan secara tepat. Teknologi modern misalnya, tidak cocok dengan corak/kehidupan desa, pola keluarga besar, usaha keluarga dan buta huruf. Adrian Sutawijaya Fakultas Ekonomi Universitas terbuka Jakarta, dalam penelitiannya yang berjudul "Pengaruh ekspor dan Investasi terhadap Pertumbuhan 
Ekonomi Indonesia Periode 1980-2006" menemukan bahwa ekspor non migas berpengaruh positif dan signifikan terhadap pertumbuhan ekonomi. Penelitian lainnya yakni oleh Meidiana Fakultas Ekonomi Universitas Lampung dengan penelitiannya yang berjudul "Analisis Pengaruh Ekspor terhadap Pertumbuhan Ekonomi Indonesia Periode 2003 sampai 2010" menemukan bahwa ekspor berpengaruh positif dan signifikan terhadap pertumbuhan ekonomi Data yang digunakan adalah data runtun waktu selama periode 2003:12010:12. Model diestimasi dengan menggunakan kuadran terkecil biasa atau OLS (Ordinary Least Square) Veronika (2008) melakukan penelitian tentang faktor-faktor yang mempengaruhi permintaan ekspor wood Indonesia di China, Singapura, dan Malaysia dalam skema Cina-AFTA. Penelitian tersebut membahas pengaruh faktor-faktor (harga ekspor wood Indonesia, harga ekspor wood brazil, nilai tukar masing-masing negara, GDP masing-masing negara, dan dummy kesepakatan Cina-AFTA terhadap volume ekspor wood Indonesia dan dampak liberalisasi perdagangan Cina-AFTA terhadap permintaan ekspor wood Indonesia.

Penelitian yang dilakukan menggunakan data kuartalan mulai dari Januari 2003 sampai dengan September 2007. Metode yang digunakan dalam penelitian ini meliputi metode deskriptif dan metode kuantitatif. Metode deskriptif digunakan untuk memberikan penjelasan tentang dampak liberalisasi perdagangan Cina-AFTA dan metode kuantitatif dengan alat analisis Ordinary Least Square (OLS)digunakan untuk menganalisis faktorfaktor yang mempengaruhi permintaan ekspor wood Indonesia di Cina, Singapura, dan Malaysia. Hasil penelitiannya menunjukkan bahwa liberalisasi perdagangan Cina-AFTA memberikan potensi pasar wood yang besar bagi Indonesia di pasar Internasional. Namun dengan adanya program Cina-AFTA yaitu normal track menyebabkan penurunan permintaan ekspor wood Indonesia di negara Cina dan Malaysia. Hal ini disebabkan karena adanya pemberlakuan kesepakatan Cina-AFTA, maka akan menurunkan permintaan ekspor wood Indonesia ke negara tujuan ekspor tersebut, karena peningkatan ekspor yang terjadi belum mampu menyaingi kualitas dan kuantitas dari negara pengekspor wood lainnya. Sedangkan faktor-faktor yang mempengaruhi volume ekspor wood Indonesia ke beberapa negara tujuan ekspor menunjukkan tidak semua peubah bebas yang digunakan dalam model berpengaruh nyata terhadap volume ekspor. Dewi (2006) melakukan penelitian tentang faktor-faktor yang mempengaruhi permintaan ekspor kopi Indonesia dari Amerika Serikat. Jenis data yang digunakan adalah data sekunder dengan runtut waktu (time series) dengan periode 1975-2004. Penelitian ini difokuskan untuk memperoleh interelasi antara permintaan ekspor kopi Indonesia dari Amerika Serikat dan faktor-faktor pendapatan perkapita Amerika Serikat, harga kopi dunia, harga the dunia, konsumsi kopi perkapita Amerika, nilai tukar mata uang dollar Amerika terhadap rupiah, dan jumlah penduduk Amerika Serikat. Teknik analisis yang dipilih adalah analisis regresi berganda dan metode yang digunakan adalah metode kuadrat terkecil atau Ordinary Least Square (OLS). Hasil penelitian yang dilakukan menunjukkan bahwa variabel pendapatan perkapita Amerika Serikat, harga kopi dunia, harga teh dunia, konsumsi kopi Amerika Serikat, dan jumlah penduduk berpengaruh secara signifikan, sedangkan nilai tukar dollar terhadap rupiah, dan pendapatan perkapita Amerika serikat berpengaruh tidak signifikan.

Berdasarkan uraian diatas Faktor yang mempengaruhi ekspor tersebut yang bisa di evaluasi oleh Negara eksportir adalah dari sisi penawaran karena indikatornya berasal dari Negara yang melakukan ekspor dalam hal ini adalah Indonesia dan Malaysia diantara variabel yang dianggap mempengaruhi adalah nilai tukar atau kurs mata uang masing- 
masing Negara terhadap dolar amerika serikat yakni rupiah Indonesia dan ringgit Malaysia terhadap dolar amerika serikat, kemudian variabel lainnya yakni pertumbuhan ekonomi dan jumlah tenaga kerja Atas dasar latar belakang tersebut di atas lah yang melatar belakangi untuk melakukan penelitian dengan judul "Analisis Pengaruh Nilai tukar, pertumbuhan ekonomi dan tenaga kerja terhadap ekspor Indonesia dan Malaysia ke China.

\section{METODE}

Gasversz (1997) mengungkapkan bahwa diagram sebab akibat ini merupakan pendekatan terstruktur yang memungkinkan dilakukan suatu analisis lebih terperinci dalam menemukan penyebab-penyebab suatu masalah, ketidaksesuaian, dan kesenjangan yang ada.

\section{Analisis deskriptif}

Merupakan analisis yang dilakukan secara deskriptif untuk memberikan gambaran mengenai perkembangan Variabel-variabel Penelitian, digunakan formula :

$$
\operatorname{Igt}=\frac{\mathrm{It}-\mathrm{It}-1}{\mathrm{It}-1} \times 100 \%
$$

Dimana:

Igt $=$ Perkembangan variabel-variabel penelitian (nilai ekspor Indonesia dan

Malaysia ke China, tenaga kerja, pertumbuhan ekonomi,dan nilai tukar)

It $=$ Variabel penelitian tahun $\mathrm{t}$

It-1 = Variabel penelitian tahun $\mathrm{t}-1$

\section{Analisis kuantitatif}

Metode analisis data yang digunakan dalam penelitian ini adalah analisis regresi berganda dengan metode data panel karena analisis tersebut dapat digunakan sebagai model prediksi terhadap suatu variabel dependen dari beberapa variabel independen yang menggunakan data time series dan cross section dengan model sebagai berikut yaitu :

Xit $=\beta_{0}+\beta_{1} K_{i t}+\beta_{2} T_{i t}+\beta_{3} P_{i t}+\varepsilon$

dimana :

$\mathrm{X} \quad$ :Nilai ekspor ke China

$\mathrm{K} \quad$ :Nilai tukar mata uang Indonesia dan Malaysia terhadap dolar Amerika

T :Tenaga kerja

$\mathrm{P} \quad$ :Pertumbuhan ekonomi

i $\quad$ :Cross section (Indonesia dan Malaysia)

t $\quad$ :Tahun 1993 sampai 2015

$\beta_{0} \quad$ :Konstanta

$\beta_{1,2,3}$ :Koefisien regresi variabel independen

$\varepsilon \quad:$ :Error term

\section{HASIL DAN PEMBAHASAN}

\section{Perkembangan nilai ekspor Indonesia ke China}

Untuk mengetahui perkembangan nilai ekspor Indonesia ke china selama periode tahun 1993 sampai tahun 2015 dapat dilihat pada Gambar 1 berikut : 


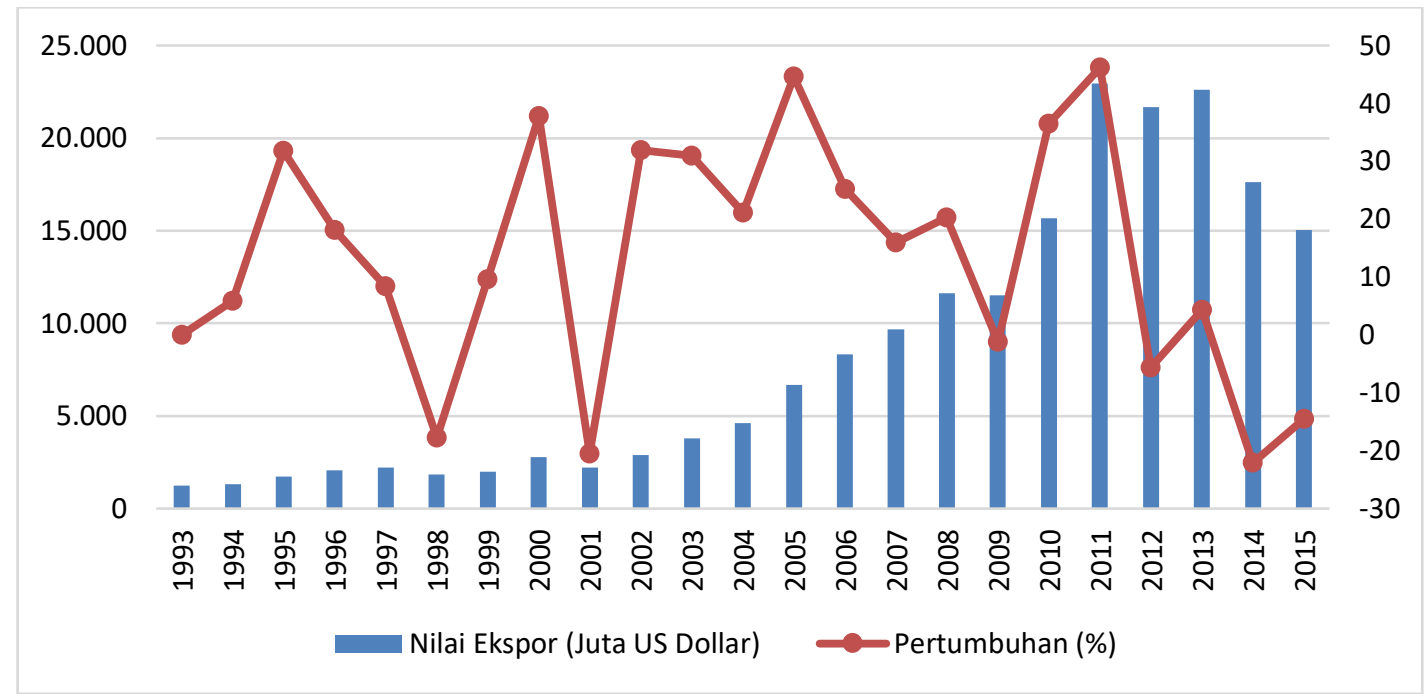

Sumber : ADB, 2015 (diolah)

Gambar 1. Perkembangan nilai ekspor Indonesia ke China Periode 1993-2015

Berdasarkan Gambar 1 diperoleh informasi selama periode tahun 1993 sampai 2015 perkembangan ekspor Indonesia mengalami fluktuasi atau naik turun dengan rata-rata pertumbuhan sebesar $13,95 \%$, dengan pertumbuhan tertinggi terjadi pada tahun 2011 yakni sebesar $46,18 \%$ dan pertumbuhan terendah terjadi pada tahun 2014 yakni $-22,10 \%$.

\section{Pertumbuhan ekonomi Indonesia perode tahun 1993 sampai tahun 2015}

Untuk mengetahui pertumbuhan ekonomi Indonesia dari tahun 1993 sampai tahun 2015 dapat dilihat pada Gambar 2 berikut ini :

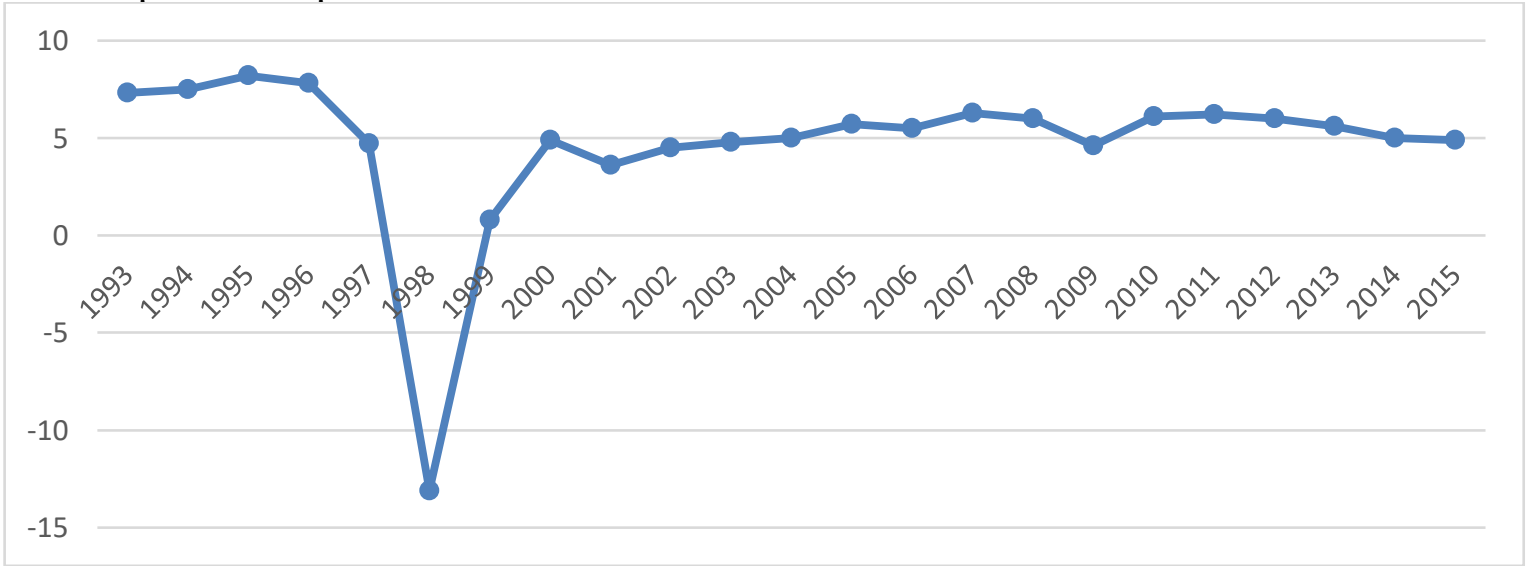

Sumber : ADB, 2020 (diolah)

Gambar 2. Pertumbuhan ekonomi Indonesia perode tahun 1993 sampai tahun 2015 (berdasarkan harga konstan 2000)

Berdasarkan dari data pada Gambar 2 menunjukkan selama periode tahun 1993 sampai 2015 pertumbuhan ekonomi Indonesia mengalami fluktuasi atau naik turun dengan rata-rata pertumbuhan ekonomi sebesar 4,69\% selama periode tersebut pertumbuhan ekonomi tertinggi terjadi pada tahun 1995 yakni 8,2\% dan pertumbuhan ekonomi terendah terjadi pada tahun 1998 yakni $-13,1 \%$ dimana pada saat itu di Indonesia terjadi krisis ekonomi. 
Perkembangan nilai tukar rupiah per US Dollar Tahun 1993 - 2015

Untuk mengetahui perkembangan nilai tukar rupiah per US Dollar periode tahun 1993 sampai tahun 2015 dapat dilihat pada Gambar 3 berikut ini :

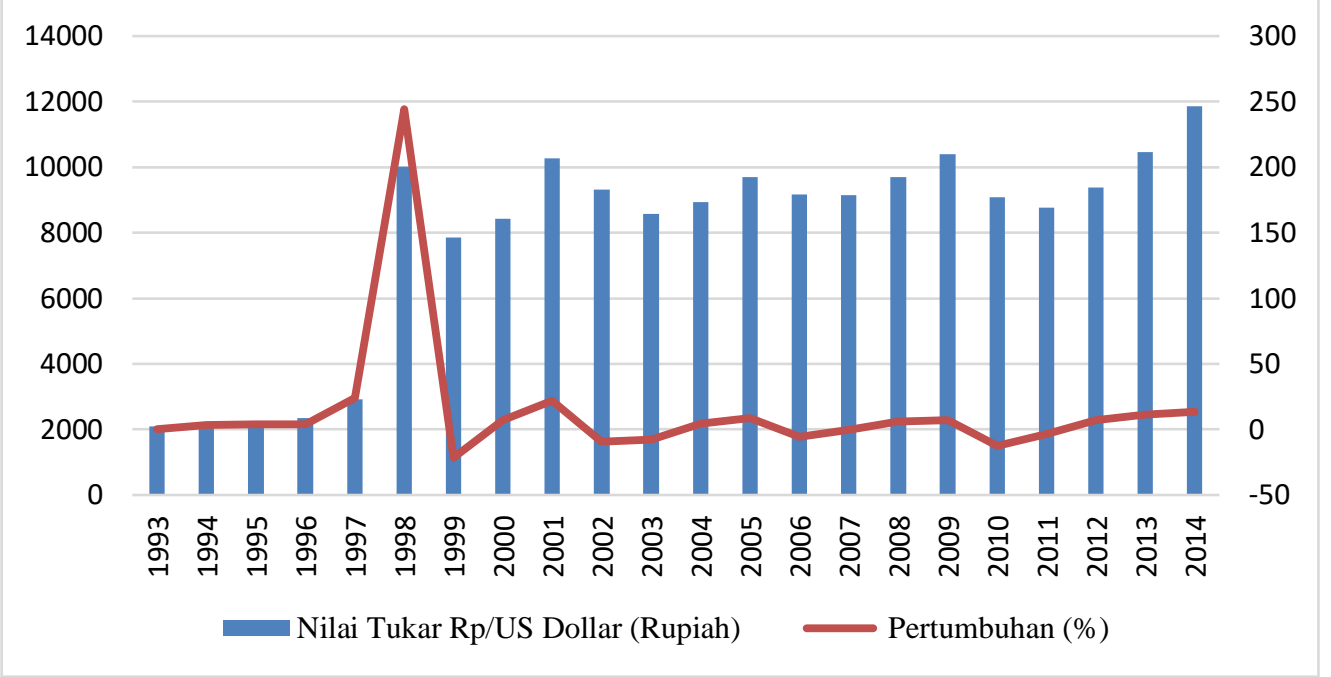

Sumber : $A D B, 2020$ (diolah)

Gambar 3. Perkembangan nilai tukar rupiah per US Dollar tahun 1993 - 2015

Berdasarkan dari data pada Gambar 3 terlihat bahwa kecendrungan nilai tukar mata uang rupiah Indonesia terhadap dollar amerika serikat mengalami pelemahan atau dengan kata lain rupiah cendrung terdepresiasi dengan rata-rata pertumbuhan sebesar 14,52\%, selama periode tersebut penguatan dolar amerika serikat tertinggi terjadi pada tahun 1998 dengan kenaikan mencapai $244,24 \%$ pada saat terjadinya krisis ekonomi dan pertumbuhan terendah terjadi pada tahun 1999 yakni $-21,55 \%$.

Perkembangan jumlah tenaga kerja Indonesia periode tahun 1993 sampai tahun 2015

Untuk mengetahui Perkembangan jumlah tenaga kerja Indonesia periode tahun 1993 sampai tahun 2015 dapat dilihat pada Gambar 4 berikut ini :

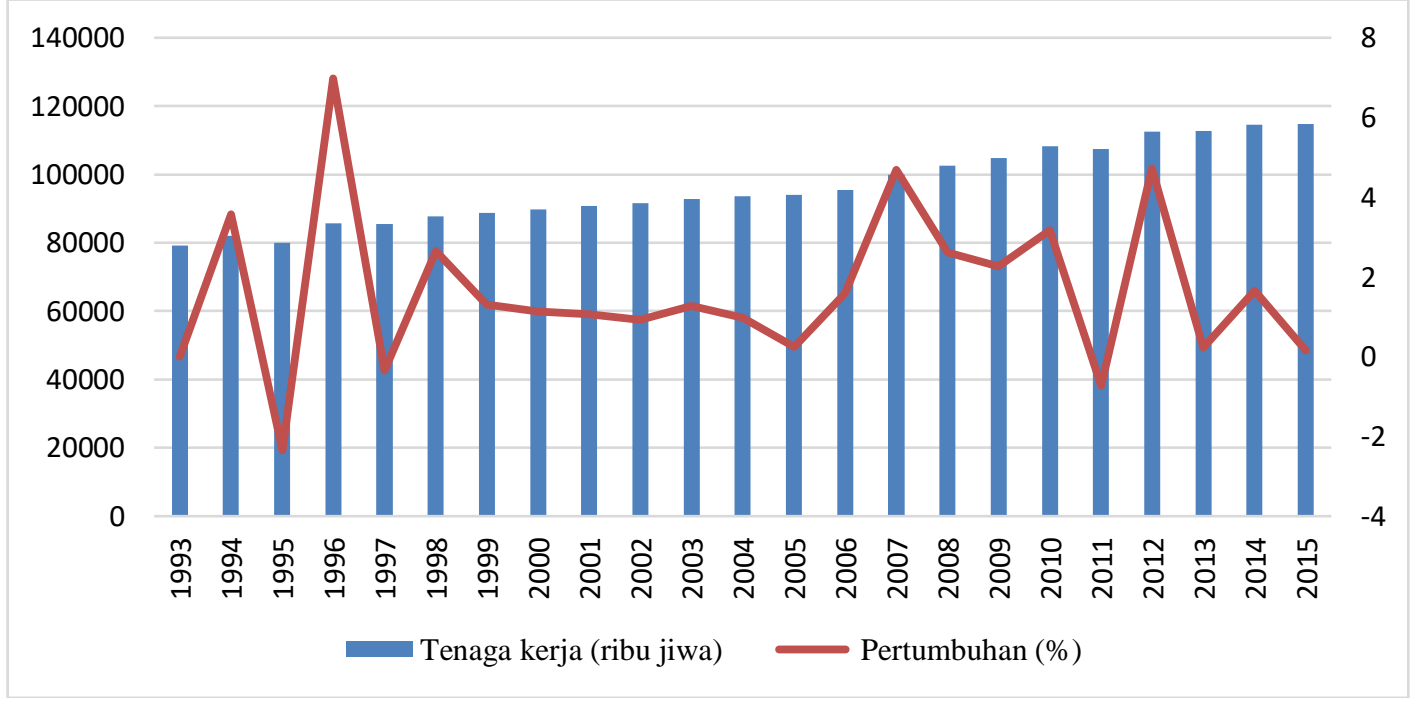

Sumber : ADB

Gambar 4. Perkembangan jumlah tenaga kerja Indonesia Tahun 1993 - 2015 
Berdasarkan data pada Gambar 4 jumlah penyerapan tenaga kerja Indonesia selama periode tahun 1993 sampai tahun 2015 mengalami fluktuasi dengan rata-rata pertumbuhan sebesar $1,72 \%$, selama periode tersebut pertumbuhan tertinggi terjadi pada tahun 1996 yakni $6,98 \%$ dan pertumbuhan terendah terjadi pada tahun 1995 yakni $-2,35 \%$.

\section{Perkembangan nilai ekspor Malaysia ke China}

Untuk mengetahui perkembangan nilai ekspor Malaysia ke china dapat dilihat pada Gambar 5 berikut ini :

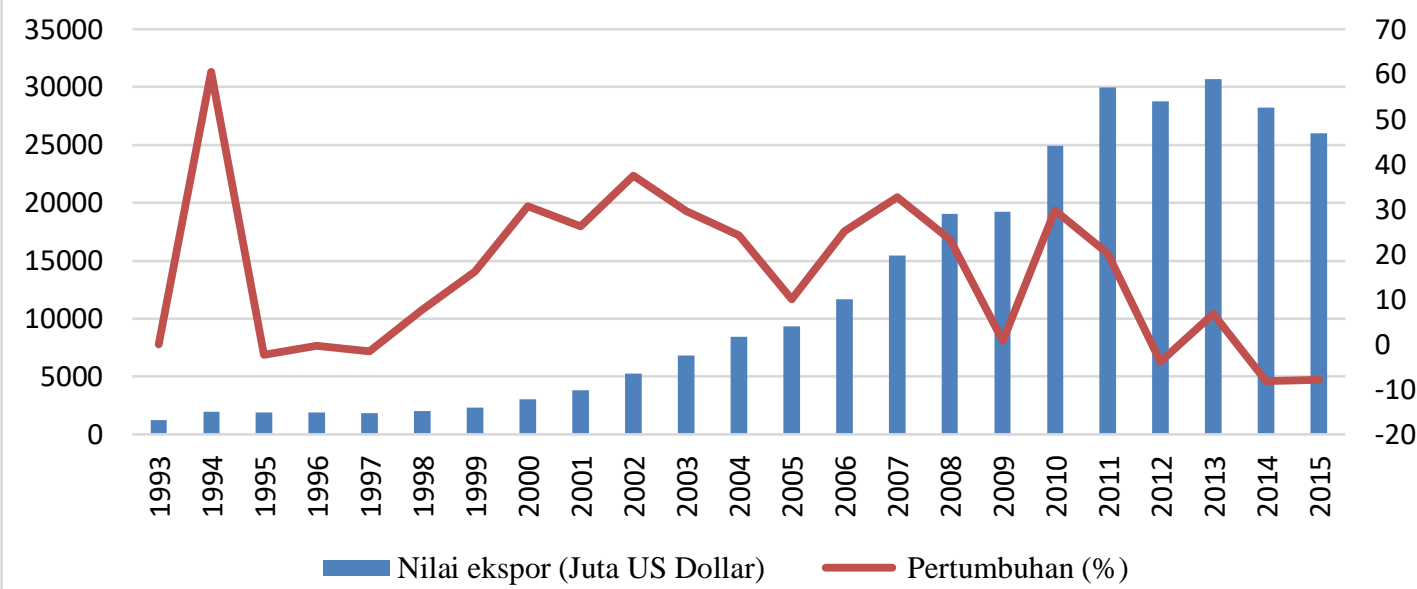

Sumber : $A D B, 2020$ (diolah)

Gambar 5. Perkembangan nilai ekspor Malaysia ke China Tahun 1993 sampai tahun 2015

Berdasarkan dari data pada Gambar 5 terlihat bahwa selama periode tahun 1993 sampai tahun 2015 nilai ekspor Malaysia ke china mengalami fluktuasi atau naik turun dengan rata-rata pertumbuhan sebesar $16,22 \%$ dengan pertumbuhan tertinggi terjadi pada tahun 1994 yakni 60,54\% dan pertumbuhan terendah pada tahun 2014 yakni $-8,16 \%$.

\section{Pertumbuhan ekonomi Malaysia periode Tahun 1993 - 2015}

Untuk mengetahui pertumbuhan ekonomi Malaysia dari tahun 1993 - 2015 dapat dilihat pada Gambar 6 berikut ini :

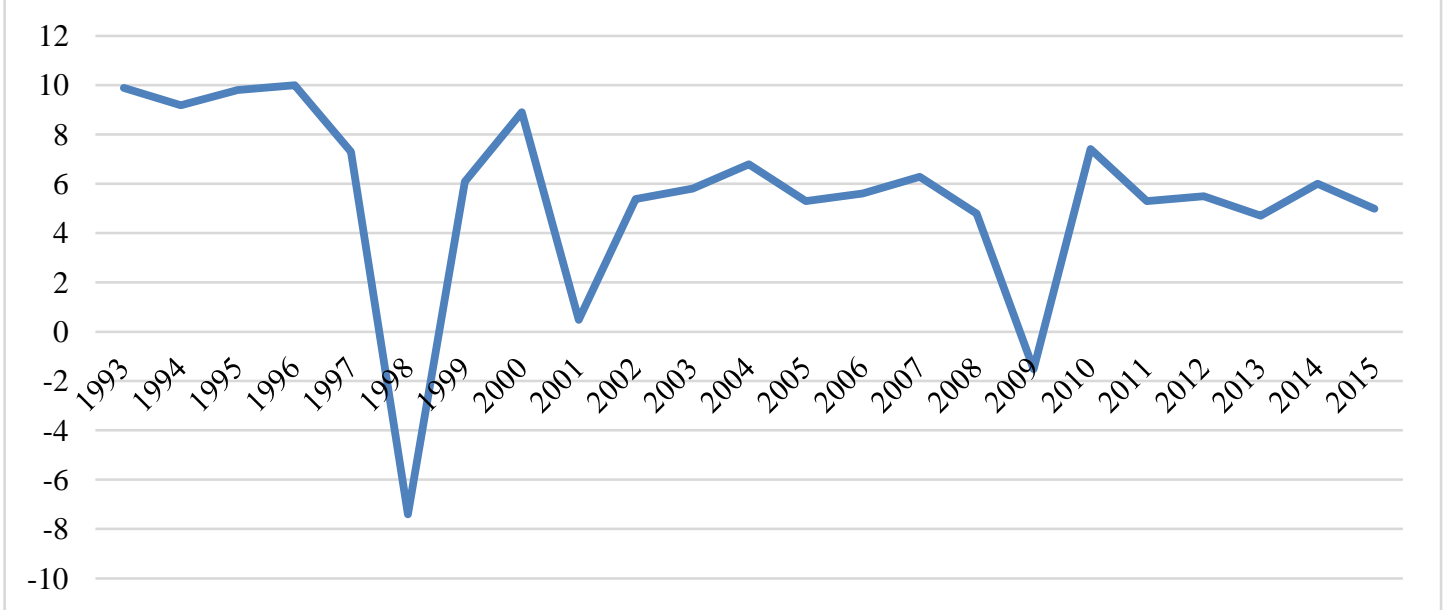

Sumber : ADB

Gambar 6. pertumbuhan ekonomi Malaysia dari tahun 1993 - 2015 
Berdasarkan data pada Gambar 6 terlihat bahwa selama periode tahun 1993 sampai 2015 pertumbuhan ekonomi Malaysia mengalami fluktuasi atau naik turun dengan rata-rata $5,5 \%$, selama periode tersebut pertumbuhan ekonomi tertinggi terjadi pada tahun 1996 yakni $10 \%$ dan pertumbuha ekonomi terendah terjadi pada tahun 1998 yakni $-7,4 \%$ dimana pada saat itu terjadi krisis ekonomi yang melanda beberapa Negara asia tenggara termasuk Malaysia.

\section{Perkembangan nilai tukar Ringgit Malaysia terhadap dollar amerika serikat}

Untuk mengetahui Perkembangan nilai tukar Ringgit Malaysia terhadap dollar amerika serikat selama tahun 1993 sampai tahun 2015 dapat dilihat pada Gambar 7 berikut ini :

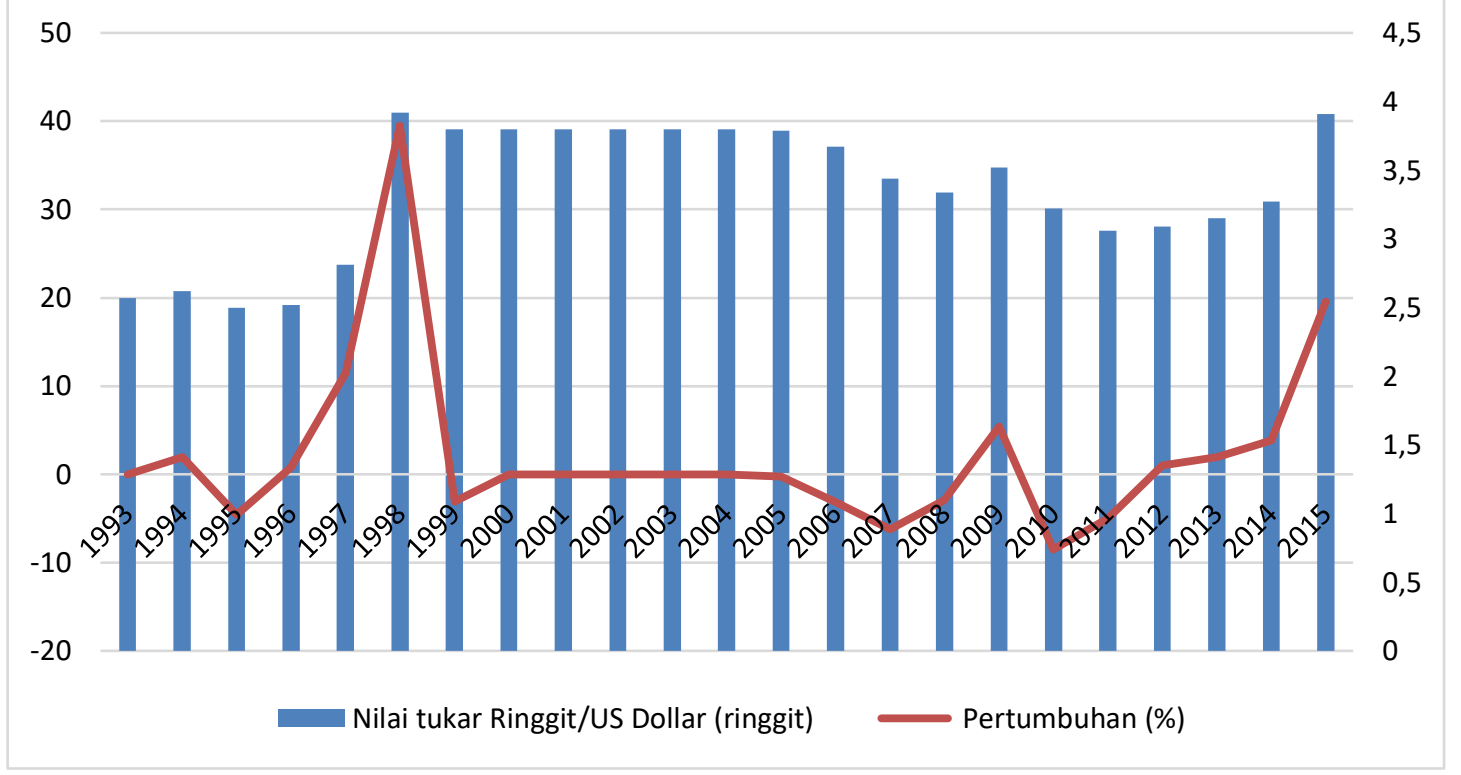

Sumber : ADB

Gambar 7. Perkembangan nilai tukar Ringgit Malaysia terhadap dollar amerika serikat

Berdasarkan dari data pada Gambar 7 nilai tukar mata uang ringgit Malaysia terhadap dollar amerika serikat selama periode tahun 1993 sampai tahun 2015 mengalami fluktuasi atau naik turun dengan rata-rata pertumbuhan $2,35 \%$ dengan pertumbuhan tertinggi terjadi pada tahun 1998 yakni 39,5\% dimana pada saat ini terjadi krisis ekonomi atau mata uang lokal melemah terhadap dolar amerika serikat atau nilai tukar mata uang dolar menguat terhadap mata uang di Negara-negara ASEAN termasuk Malaysia, dan pertumbuhan terendah terjadi pada tahun 2010 yakni $-8,52 \%$.

\section{Perkembangan jumlah tenaga kerja Malaysia dari tahun 1993 sampai tahun 2015}

Untuk mengetahui perkembangan jumlah tenaga kerja Malaysia dari tahun 1993 sampai tahun 2015 dapat dilihat pada Gambar 8. Berdasarkan data pada tabel diatas terlihat selama periode tahun 1993 - 2015 pertumbuhan tenaga kerja Malaysia berfluktuasi atau naik turun dengan rata-rata pertumbuhan sebesar 2,99\%. Pertumbuhan tertinggi terjadi pada tahun 2010 sebesar 9,20\% dan pertumbuhan terendah terjadi pada tahun 1998 yakni 0,36\%. 


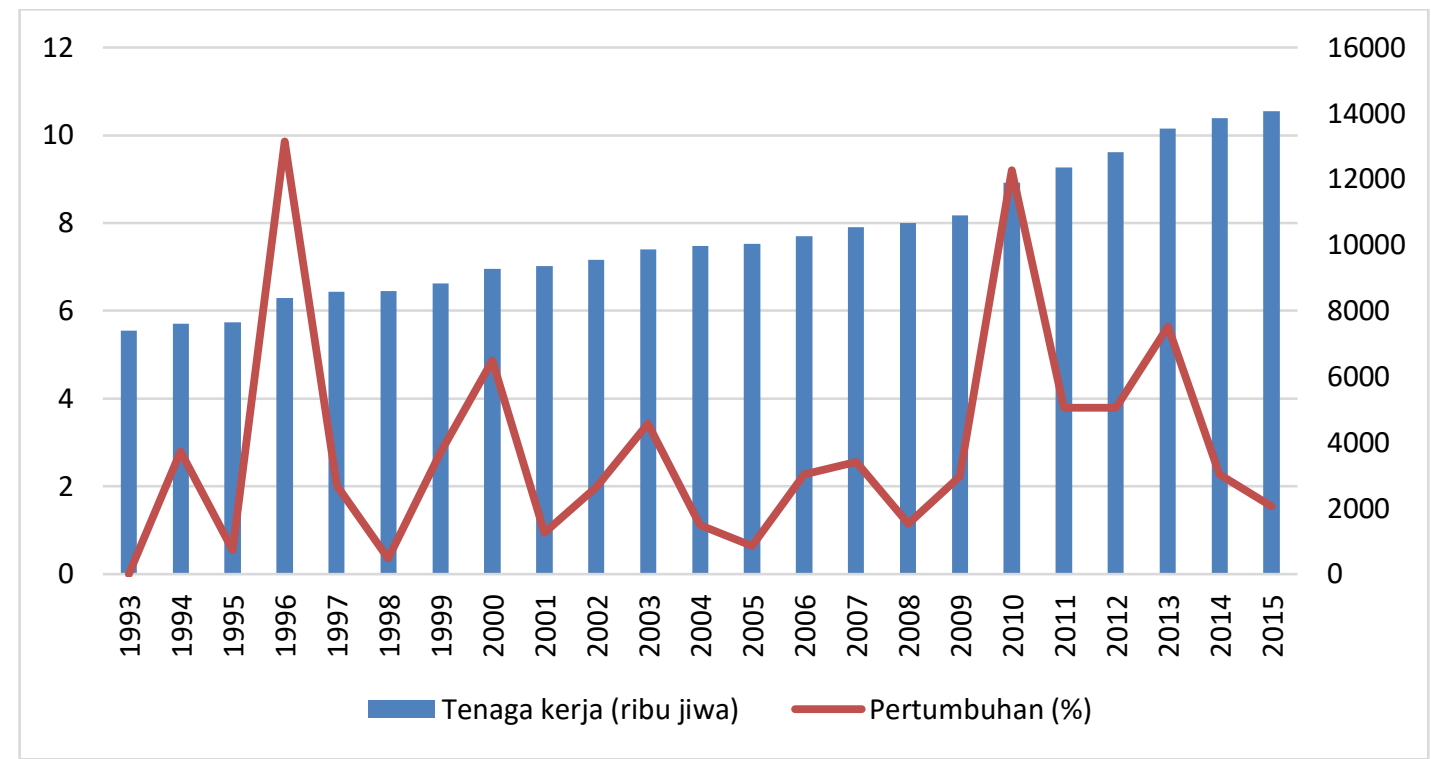

Sumber : ADB

Gambar 8. Perkembangan jumlah tenaga kerja Malaysia dari tahun 1993 sampai 2015

Pengaruh nilai tukar, pertumbuhan ekonomi dan tenaga kerja terhadap ekspor

Dari tabel diatas terlihat bahwa nilai probabilitas F kurang dari alpha lima persen sehingga Ho (common effect) ditolak dan Ha (Fixed effect) di terima sehingga disimpulkan model panel yang terbaik adalah model Fixed effect yang dapat dilihat pada Tabel 1 berikut:

Tabel 1. Hasil regresi fixed effect model

\begin{tabular}{crrrr}
\hline Variable & Coefficient & Std. Error & t-Statistic & Prob. \\
\hline C & -43927.09 & 8482.251 & -5.178707 & 0.0000 \\
PE? & -352.6653 & 275.3422 & -1.280826 & 0.2075 \\
K? & -2.084230 & 0.730099 & -2.854722 & 0.0067 \\
TK? & 1.210702 & 0.204104 & 5.931781 & 0.0000 \\
Fixed Effects (Cross) & & & \\
_IND--C & -45785.22 & & \\
_MAL--C & 45785.22 & & \\
\hline \multicolumn{5}{c}{ Eross-section fixed (dummy variables) } \\
R-squared & 0.540232 & Mean dependent var & 10341.98 \\
Adjusted R-squared & 0.495377 & S.D. dependent var & 9511.176 \\
S.E. of regression & 6756.438 & Akaike info criterion & 20.57670 \\
Sum squared resid & 1.87 E+09 & Schwarz criterion & 20.77547 \\
Log likelihood & -468.2641 & Hannan-Quinn criter. & 20.65116 \\
F-statistic & 12.04386 & Durbin-Watson stat & 0.252341 \\
Prob(F-statistic) & 0.000001 & & \\
\hline
\end{tabular}

Sumber: Data diolah,2020

Untuk menentukan model regresi panel data yang dipakai digunakan redundant tes dengan hasil sebagai berikut : 
Tabel 2. Hasil uji redundant data panel

\section{Pool: POOL1}

Test cross-section fixed effects

Effects Test

Cross-section F

Statistic

d.f. Prob.

Cross-section Chi-square

45.342925

$(1,41) \quad 0.0000$

Sumber: Data diolah, 2020

\section{Uji F}

Nilai F hitung sebesar 12,04 dengan probabilitas kecil dari alpha 1\% sehingga dapat disimpulkan secara bersama-sama variabel nilai tukar, pertumbuhan ekonomi dan tenaga kerja berpengaruh signifikan terhadap ekcpor ke china

\section{Uji t}

Nilai t hitung untuk variabel pertumbuhan ekonomi sebesar 1,28 dengan probabilitas 0,20 besar dari batas toleransi alpha 10\% sehingga disimpulkan pertumbuhan ekonomi tidak berpengaruh signifikan terhadap ekspor ke china, sementara variabel kurs nilai $t$ hitung nya sebesar 2,85 dengan probabilitas 0,0067 lebih kecil dari nilai alpha $1 \%$ sehingga disimpulkan variabel kurs berpengaruh signifikan terhadap ekspor ke china, dan variabel tenaga kerja nilai t hitungnya sebesar 5,93 dengan probabilitas mendekati nol kecil dari alpha $1 \%$ sehingga disimpulkan variabel tenaga kerja berpengaruh signifikan terhadap ekspor ke china.

\section{Uji koefisien determinasi}

Dari hasil regresi pada tabel diatas diperoleh nilai $\mathrm{R}$ square sebesar 0,54 artinya 54\% perubahan niali ekspor ke china dipengaruhi oleh pertumbuhan ekonomi,kurs dan tenaga kerja.

\section{Interpretasi hasil regresi}

Berdasarkan hasil regresi diperoleh persamaan regresi sebagai berikut :

Ekspor ke china $=-43927,09-352,6$ Pertumbuhanekonomi $-2,08$ Kurs $+1,21$ Tenagakerja + e. Angka konstanta -43927,09 Artinya pada saat semua variabel bebas yakni pertumbuhan ekonomi,kurs dan tenaga kerja nilainya pada posisi nol maka ekspor ke china sebesar -43927,09 dalam juta US dollar, sedangkan nilai koefisien regresi pertumbuhan ekonomi 352,6 menunjukkan jika ekonomi tumbuh 1\% maka ekspor ke china turun sebesar 352,6 juta us dollar namun nilai tersebut jadi tidak bermakna karena secara uji $t$ pertumbuhan ekonomi tidak berpengaruh signifikan,sementara nilai koefisien regresi kurs 2,08 bermakna jika nilai tukar mata uang masing-masing Negara terdepresiasi 1 satuan mata uang masing-masing Negara (Rupiah Indonesia dan Ringgit Malaysia ) maka ekspor ke china akan turun sebesar 2,08 Juta US dollar, sementara koefisien regresi tenaga kerja sebesar 1,21 menunjukkan bahwa jika terjadi kenaikkan tenaga kerja satu dalam satuan ribu jiwa maka ekspor ke china akan naik sebesar 1,21 Juta US dollar.

\section{Implikasi hasil penelitian}

Berdasarkan hasil penelitian secara kuantitatif dengan model regresi data panel menunjukkan bahwa variabel pertumbuhan ekonomi tidak berpengaruh signifikan terhadap ekspor ke china hal ini mengindikasikan bahwa kenaikan output pendapatan nasional tidak 
dapat menggerakkan ekspor ke china dengan berbagai metode penghitungan pendapatan nasional jika menggunakan indikator PDB (produk domestik bruto) maka PDB tidak murni milik warga Negara tapi warga Negara asing juga ikut berkontribusi dan pertumbuhan bisa saja didorong oleh konsumsi sehingga efeknya tidak ada bagi peningkatan ekspor ke china.

Sementara untuk variabel nilai tukar atau Kurs hasilnya menunjukkan pengaruh negatif dan signifikan terhadap ekspor ke china hal ini menunjukkan bahwa jika mata uang dollar terus mengalam penguatan terhadap mata uang masing-masing Negara yakni Rupiah Indonesia dan Ringgit Malaysia maka nilai ekspor ke china akan turun hal ini mengindikasikan bahwa barang-barang ekspor yang di ekspor ke china komponen atau bahan bakunya juga masih tergantung drai barang-barang impor sehingga jika dollar amerika menguat maka bahan baku tersebut juga akan naik sehingga biaya produksi untuk barang ekspor pun akan meningkat. Walaupun dalam jangka pendek harga barang ekspor lebih murah karena nilai tukar mata uang lokar terdepresiasi namun dalam jangka panjang akan berdampak negative jika barang tersebut masih menggunakan kompone impor.

Sementara untuk variabel tenaga kerja menunjukkan hasil positif dan signifikan terhadap ekspor ke china hal ini mengindikasikan bahwa barang barang yang di eskpor ke china membutuhkan input atau faktor produksi tenaga kerja sehingga dengan semakin banyaknya tenaga kerja maka output atau barang dan jasa yang dihasilkan juga akan meningkat sehingga dapat di eskpor ke Negara lain khususnya china.

\section{KESIMPULAN DAN SARAN}

Perkembangan ekspor Indonesia ke China berfluktuasi atau naik turun selama periode Tahun 1993 sampai 2015 dengan rata-rata 13,95\%,sementara nilai tukar rupiah terhadap dolar Amerika Serikat serta pertumbuhan ekonomi juga berfluktuasi rata-rata pertumbuhan nilai tukar rupiah terhadap dolar Amerika Serikat sebesar 14,52\%, dan rata-rata pertumbuhan ekonomi sebesar 4,69\% tenaga kerja juga berfluktuasi dengan rata-rata pertumbuhan $1,72 \%$.

Perkembangan ekspor Malaysia ke China juga berfluktuasi atau naik turun selama periode tahun 1993 sampai 2015 dengan rata-rata 16,22\%,sementara nilai tukar ringit terhadap dolar Amerika Serikat serta pertumbuhan ekonomi juga berfluktuasi rata-rata pertumbuhan nilai tukar ringgit terhadap dolar Amerika Serikat sebesar 2,35\%, dan ratarata pertumbuhan ekonomi sebesar 5,5\% tenaga kerja juga berfluktuasi dengan rata-rata pertumbuhan $2,99 \%$.

Berdasarkan hasil regresi data panel menunjukkan variabel kurs berpengaruh negatif signifikan terhadap ekspor ke China, variabel tenaga kerja berpengaruh positif dan signifikan terhadap ekspor ke China, sementara variabel pertumbuhan ekonomi tidak berpengaruh signifikan terhadap ekspor ke China.

\section{DAFTAR PUSTAKA}

ADB. (2014). Economic Indicators, diakses dalam www.adb.org, Tanggal 10 juli 2020, Pukul 10.00 WIB

Adrian Sutawijaya. (2010). Pengaruh ekspor dan Investasi terhadap Pertumbuhan Ekonomi Indonesia Periode 1980-2006, Jurnal Organisasi Dan Manajemen,6(1), 14-27. Retrieved from http://jurnal.ut.ac.id/index.php/jom/article/view/265

Anggraini, Dewi. (2006). Faktor-faktor yang mempengaruhi permintaan ekspor kopi Indonesia dari Amerika Serikat, Tesis, Pascasarjana UNDIP, Semarang 
Badan pusat statistik. (2020). Indikator sosial ekonomi Indonesia berbagai Edisi. diakses dalam http://bps.go.id, Tanggal 10 Juli 2020, Pukul 10.00 WIB

Boediono. (1981). Teori pertumbuhan ekonomi, BPFE: Yogyakarta.

Dornbusch.R. (2001). Macro economic, The Mc Graw Hill Companies.Inc: New york

Dumairy.(1996). Perekonomian Indonesia : PT. Airlangga: Jakarta

E Emilia, R Nurjanah. (2015).Analisis Pengaruh Ekspor ke China terhadap pendapatan perkapita dan Penyerapan tenaga kerja di indonesia, Jurnal Paradigma Ekonomika $10(2)$

Gaspersz, Vincent. (1997). Manajemen kualitas penerapan konsep-konsep kualitas dalam manajemen bisnis total. PT. Gramedia Pustaka Utama: Jakarta

Greene H. William. (2000). Econometric Analysis, $4^{\text {th }}$ Edition, Prentice-Hall, New Jersey.

Gujarati, Damodar N. (2003), Basic econometrics. Fourth edition, International Edition. MC Grow Hill.

Jhingan, M.L. (1993). Ekonomi pembangunan dan perencanaan, Edisi ke-16, PT. Raja Grafindo Persada: Jakarta.

Lindert, Peter H. (1994). Ekonomi Internasional (Edisi 9), Bumi Aksara: Jakarta.

Mudrajad Kuncoro. (2003). Metode riset untuk bisnis dan ekonomi: Bagaimana Meneliti dan Menulis Tesis?, Erlangga: Jakarta

Nopirin. (1991). Ekonomi Intrenasional, BPFE UGM: Yogyakarta

Sutawijaya, Adrian. (2010). Pengaruh ekspor dan investasi terhadap pertumbuhan ekonomi Indonesia Periode 1980-2006. Jurnal Organisasi dan Manajemen, 6 (1), 14-27

T.Froyen. (2005). Macro economics, theories and policies, Eight edition. Prentice Hall: Pearson

Todaro, Michael P. and Stephen C. Smith. (2003). Economic development, Eight Edition.The Addison.Wesley. George Washington University: Pearso

Van den Berg, Hendrik. (2001). Economic growth and development, International Edition, The Mc Graw Hill Companies.Inc: New York

Veronika,Liana (2008). Faktor-faktor yang mempengaruhi permintaan ekspor wood Indonesia di China, Singapura, dan Malaysia dalam skema Cina-AFTA. Fakultas Ekonomi dan Manajemen IPB: Bogor 